\title{
Review \\ Quantitative and Qualitative Platelet Derangements in Cardiac Surgery and Extracorporeal Life Support
}

\author{
Enrico Squiccimarro ${ }^{1,2,3,+} \mathbb{D}$, Federica Jiritano ${ }^{3,4, *}++^{\mathbb{D}}$, Giuseppe Filiberto Serraino ${ }^{4}$, Hugo ten Cate ${ }^{5,6,7}(\mathbb{D}$, \\ Domenico Paparella ${ }^{8,9}$ (D) and Roberto Lorusso ${ }^{3,7}$
}

1 Department of Cardiac Surgery, Mater Dei Hospital, 70125 Bari, Italy; e.squiccimarro@gmail.com

2 Department of Emergency and Organ Transplant (DETO), University of Bari, 70125 Bari, Italy

3 Cardio-Thoracic Surgery Department, Heart \& Vascular Centre, Maastricht University Medical Centre (MUMC), 6229HX Maastricht, The Netherlands; robertolorussobs@gmail.com

4 Cardiac Surgery Unit, Department of Experimental and Clinical Medicine, University "Magna Graecia" of Catanzaro, 88100 Catanzaro, Italy; serraino@unicz.it

5 Center for Thrombosis and Hemostasis (CTH), University Medical Center of the Johannes Gutenberg-University Mainz, D-55131 Mainz, Germany; h.tencate@maastrichtuniversity.nl

6 Thrombosis Center Maastricht, Maastricht University Medical Center (MUMC), 6229HX Maastricht, The Netherlands

7 Cardiovascular Research Institute Maastricht (CARIM), 6229HX Maastricht, The Netherlands

8 Division of Cardiac Surgery, Santa Maria Hospital, GVM Care \& Research, 70125 Bari, Italy; domenico.paparella@uniba.it

9 Department of Medical and Surgical Sciences, University of Foggia, 71122 Foggia, Italy

* Correspondence: fede.j@hotmail.it

+ These authors equally contributed to this work.

Citation: Squiccimarro, E.; Jiritano, F.; Serraino, G.F.; ten Cate, H.; Paparella, D.; Lorusso, R. Quantitative and Qualitative Platelet Derangements in Cardiac Surgery and Extracorporeal Life Support. J. Clin. Med. 2021, 10, 615. https:// doi.org/10.3390/jcm10040615

Academic Editor: Tamam Bakchoul Received: 8 December 2020

Accepted: 3 February 2021

Published: 6 February 2021

Publisher's Note: MDPI stays neutral with regard to jurisdictional claims in published maps and institutional affiliations.

Copyright: (c) 2021 by the authors. Licensee MDPI, Basel, Switzerland. This article is an open access article distributed under the terms and conditions of the Creative Commons Attribution (CC BY) license (https:/ / creativecommons.org/licenses/by/ $4.0 /)$.

\begin{abstract}
Thrombocytopenia and impaired platelet function are known as intrinsic drawbacks of cardiac surgery and extracorporeal life supports (ECLS). A number of different factors influence platelet count and function including the inflammatory response to a cardiopulmonary bypass (CPB) or to ECLS, hemodilution, hypothermia, mechanical damage and preoperative treatment with platelet-inhibiting agents. Moreover, although underestimated, heparin-induced thrombocytopenia is still a hiccup in the perioperative management of cardiac surgical and, above all, ECLS patients. Moreover, recent investigations have highlighted how platelet disorders also affect patients undergoing biological prosthesis implantation. Though many hypotheses have been suggested, the mechanism underlying thrombocytopenia and platelet disorders is still to be cleared. This narrative review aims to offer clinicians a summary of their major causes in the cardiac surgery setting.
\end{abstract}

Keywords: platelet; thrombocytopenia; cardiac surgery; inflammation; biological prosthesis; extracorporeal life support

\section{Introduction}

Platelets are anucleated blood components with a pivotal role in hemostasis and also other functions in the biology and pathophysiology of complex diseases [1]. Beyond hemostasis and thrombosis, contemporary knowledge ascribes to platelets a key role also in inflammation and innate immunity [2-5]. Therefore, platelets may be considered as immune cells [6]. Quantitative and qualitative platelet derangements represent a shortcoming in cardiac surgery and extracorporeal life supports (ECLS). Thrombocytopenia, indeed, is an intrinsic drawback of cardiac surgery with a prevalence $>30 \%[7,8]$. It is not a trivial event but rather a clinically relevant entity independently associated with increased postoperative morbidity and mortality $[7,8]$. A conclusive knowledge about the causes of the phenomenon is lacking whereas certainty of its clinical implications exists [9].

Therefore, beyond the role of platelets in hemostasis and thrombosis, the present review aims to give a comprehensive analysis of platelet behavior in the cardiac surgery setting (Figure 1). 


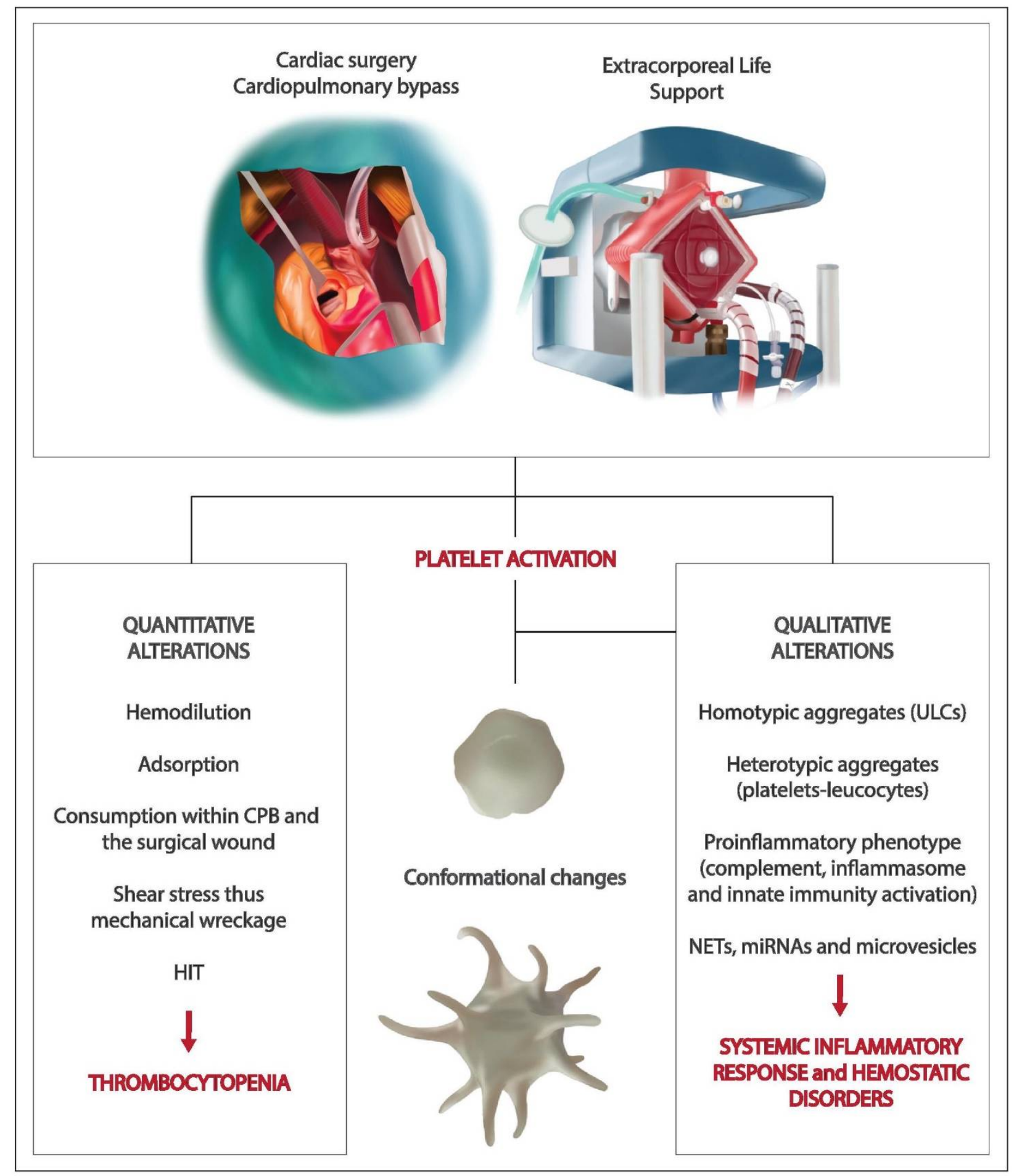

Figure 1. Platelet activation as a consequence of cardiopulmonary bypass-assisted cardiac surgery and extracorporeal life support. A summary of quantitative and qualitative platelet derangements. Abbreviations: cardiopulmonary bypass (CPB), heparin-induced thrombocytopenia (HIT), ultra-large antigenic complexes (ULCs), neutrophil extracellular traps (NETs), microRNAs (miRNAs).

2. Platelets, Cardiac Surgery and Extracorporeal Circulation: The Axis of Hemostasis, Inflammation and Innate Immunity

Multiple sides of platelet biology greatly impact on heart procedures because cardiac surgery enhances a systemic immuno-inflammation response, platelet activation and the coagulation cascade [10]. 
Platelets undergo both quantitative and qualitative alterations throughout a cardiopulmonary bypass $(\mathrm{CPB})$, the extracorporeal circulation applied to cardiac surgery procedures. The interaction between blood and artificial surfaces of the CPB triggers damage to several cells, the release of various inflammatory cytokines and the activation of the complement and coagulation-fibrinolysis systems [11,12]. During a CPB, platelet changes are caused by hypothermia, shear stress, extensive exposure to artificial surfaces and the use of exogenous drugs (heparin and protamine) [11,12]. Moreover, the coagulation cascade also begins with the activation of factor XII. Clotting factor activation occurs and initiates the subsequent activation of kallikrein, the kinin-bradykinin system and the fibrinolytic and complement cascades [11,12]. All of these mechanisms lead to increased postoperative outcomes such as mortality, major complications (e.g., stroke, acute kidney injury, postoperative infections) and a prolonged in-hospital length of stay [7]. Moreover, the hemodilution related to a $\mathrm{CPB}$ contributes to increasing the rate of thrombocytopenia [10-12]. Therefore, cardiac surgery and a CPB lead to a complex homeostatic alteration that enhances the so-called "thromboinflammation", a complex mechanism involving inflammation, thrombosis and innate immunity $[10,11]$. The same scenario occurs also as a response to other triggers such as veno-arterial (V-A) and veno-venous (V-V) extracorporeal membrane oxygenation (ECMO) and cardiac prosthetic devices $[1,13,14]$.

Moreover, a major role is attributed to the direct platelet-leucocyte interaction that bidirectionally boosts their reciprocal activation [15]. This cross-talk is fundamental in the multistep pathway of neutrophil extravasation (i.e., margination, rolling, extravasation and migration) that occurs in the systemic inflammatory response syndrome in patients on a CPB $[16,17]$. This process causes the activation of the endothelial cells and of several cellular adhesion molecules (CAMs) resulting lastly in tissue metabolic impairments and an ischemia-reperfusion injury (IRI) [16,17]. Moreover, the interplay between platelets and neutrophils was reported as a prerequisite for the release of neutrophil extracellular traps (NETs), which further triggers platelet activation and aggregation $[18,19]$. Furthermore, the binding of platelets' integrin $\alpha \mathrm{Ilb} \beta 3$ to neutrophils' macrophage- 1 antigen (Mac-1) stimulates the signaling leading to the formation of NETs. This interaction activates an inflammatory response mediated by the nuclear factor-kB (NF-kB) [20-23].

Platelets also modulate the immunoactivity of monocytes/macrophages by NF-kB activation. Moreover, the synthesis of proinflammatory mediators is stimulated. Platelets promote monocytes' chemokines synthesis via P-selectin/P-selectin glycoprotein ligand (PSGL)-1 axis mediated "regulated on activation, normal T cell expressed and secreted" (RANTES) activation [24]. Furthermore, platelet $\alpha$-granules (their most abundant storage granules) contain a diverse range of cytokines and chemokines among which are CXCL1, platelet factor 4 (PF4; CXCL4), CXCL5, interleukin-8 (IL-8) and RANTES [25]. Platelets have also been shown to independently enhance the inflammatory cascade in innate immune cells in vivo, thus contributing to the release of IL-1 cytokines [26].

In addition to these direct and indirect biological mechanisms, platelets also interact with the classical and the alternative pathways of the complement system [27]. The release of chondroitin sulfate modulates complement activity promoting anaphylatoxins and membrane attack-complex (MAC) generation, thus inducing further platelet activation [28,29]. The interplay between platelets and the complement system seems to involve platelet microparticles containing complement components such as C5b-9 at their surface [30,31].

Furthermore, platelets are the main source of microparticles in the bloodstream [32]. Extracellular vesicles composition varies and includes chemokines, cytokines and CAMs as well as small non-coding RNAs called microRNA (miRNA) [33,34]. MiRNA are involved in gene expression via negative post-transcriptional regulation [33,34]. Circulating miRNAs (i.e., miR-223 and miR-499) were detected following thrombin stimulation [34,35]. Even if the underlying mechanism is still to be cleared, miRNAs could transfer genetic material to recipient cells (among which are endothelial and immune cells) impacting the biological functions of recipient cells (i.e., regulating CAMs expression) [34,35]. Indeed, plasma exosomal miR-223 concentration was found to increase after $\mathrm{CPB}$ onset and to downregulate 
the inflammatory response reducing IL-6 and NLRP3 expression in monocytes [36]. A few studies have suggested that platelet microparticles may also be a source of a circulating tissue factor, explaining the activation of the extrinsic coagulation cascade and again linking hemostasis with immuno-inflammation via platelet activity [37].

Therefore, platelets contain abundant RNAs even if they lack a nucleus. Intraplatelet miRNA alterations may influence platelet messenger RNAs and consequently their proteome. Platelet protein expression impairment may further contribute to postoperative platelet dysfunction. A platelet qualitative impairment such as a reduced surface GPIb expression was found to be associated with the overexpression of some miRNAs (i.e., mir-10b and mir-96) and also with enhanced platelet Bax apoptotic signaling in cardiac surgery cohorts [38,39]. Microcirculatory impairment is another factor associated with platelet dysfunction following heart procedures. It consists of the loss of capillary density and increased flow heterogeneity and reflects how endothelial activation and glycocalyx degradation are both a consequence and a determinant of the systemic inflammatory response [40-42]. Furthermore, a recent investigation showed how perivascular mast cells were activated through the release of the lipid mediator platelet activating factor (PAF) from gut microvascular endothelial-adherent platelets to explain the inflammatory mediated tissue damage and organ injury following a CPB [43]. This mechanism might highlight platelets as a direct determinant of IRI related tissue damage.

\section{Platelets and Extracorporeal Membrane Oxygenation}

ECMO is a temporary mechanical support for severe cardiac or respiratory failure or both $[44,45]$. Although the technology is almost identical, ECMO and a CPB differ in many aspects such as the setting of the application, the duration of the support and the rates of complications. Despite fifty years of continuous improvement in technology and management, ECMO has weaknesses to be overcome [46]. Thrombocytopenia and platelet dysfunction are ECMO shortcomings whose underlying mechanisms remain not fully understood.

First, the alteration in the phenotype and thrombocytopenia of platelets could be the result of a huge inflammatory response. As in $\mathrm{CPB}$ patients, activated platelets circulate in the bloodstream of patients on ECMO following contact with the circuit's artificial surfaces [47]. Blood exposure to non-physiological conditions promotes thrombotic events [47].

Secondly, the high-speed rotation of the centrifugal pump triggers a mechanical shear stress causing platelet dysfunction, rupture and the shedding of receptors [48]. In a recent ex vivo study, Sun and colleagues demonstrated the pivotal role of the oxygenator, pump and circuit in affecting platelet function [49]. Platelet receptor shedding and a persistent release in microparticles confirmed a deficient adhesion and platelet count reduction increasing over time [49]. Similarly, a decreased binding capacity of platelets was demonstrated by the loss of surface receptors [50-52]. Cannulation sites and components of the circuits have also been investigated to identify how they could alter platelet shape, function and count [53]. Fuchs and colleagues indicated the pump as the largest site risk for platelet activation followed by the reinfusion cannula and lastly the connectors [53].

Thirdly, as systemic anticoagulation is required, patients are likely to develop heparininduced thrombocytopenia (HIT) [54]. The Extracorporeal Life Support Organization (ELSO) anticoagulation guideline recommends the administration of antithrombotic therapy during ECMO; unfractionated heparin (UFH) is widely administered [54,55]. The prevalence of HIT in adult ECMO patients is estimated at $3.7 \%$ with a similar prevalence between V-A and V-V ECMO $[55,56]$. However, this result could be biased by prompt HIT recognition and switching to alternative anticoagulants [56]. Frequently, physicians treat a patient by just thinking about HIT and without a solid diagnosis. Therefore, an agreed international protocol is strongly required for the early identification and univocal management of HIT patients in ECMO.

Other speculations have been advanced to justify thrombocytopenia during the ECMO run [57-59]. 
A few studies have focused attention on the duration of support and platelet count decrease [57-59]. Ang and colleagues showed how time on ECMO directly induced thrombocytopenia and the need for blood product transfusions, particularly platelets [60]. However, several factors such as a pre-existent disease (i.e., sepsis and postcardiotomy cardiogenic shock), antiplatelet drugs and bleeding events could have biased the authors' results. Panigada and co-workers observed similar outcomes in their cohort study [58]. Abrams first stated that platelet count reduction was mostly due to the severity of the disease of patients rather than related to the duration of ECMO support [57]. In a recent meta-regression, we confirmed that a worsening in thrombocytopenia was independent of the number of days on ECMO [56]. However, we speculated that after few days the inflammatory response induced by ECMO might not affect the freshly generated platelets due to the beginning of an endothelization mechanism of the circuit $[56,61,62]$.

The ECMO mode also does not seem to influence the degree of thrombocytopenia [56]. After analyzing the available evidence in the literature, we estimated a comparable platelet count decrease in almost $25 \%$ and $23 \%$ of adult V-A and V-V ECMO subjects, respectively [56].

However, in addition to the causes, future research should focus on the possible clinical implications of platelet disorders (i.e., hemorrhagic or thrombotic events, blood product transfusions and mortality). Currently, the literature lacks trials that centrally address this issue. Researchers will have to face the multiple biases (i.e., pre-existing diseases, anticoagulation and antiplatelet drugs, sepsis) that make the investigation a real challenge.

\section{Platelets and Aortic Biological Prosthesis}

In the past years, physicians have had to cope with periprocedural thrombocytopenia in patients receiving an aortic biological prosthesis [63]. The discussion has focused on blood interaction with the artificial valves and the possible consequences [63]. An increased platelet turnover and destruction plays an important role [63]. Moreover, a major bleeding risk after an aortic valve replacement is not an uncommon event ranging from $4 \%$ for surgical tissue valves to $16 \%$ for the transcatheter prosthesis [63]. The shear stress through an artificial device has been suggested as a central mechanism of hemostatic dysfunction [64,65]. It can induce conflicting mechanisms at the same time; platelet activation, aggregation and generation of procoagulant microparticles as well as platelet dysfunction, loss of surface receptors and bleeding complications $[64,65]$. Furthermore, patients receiving surgical bioprostheses are exposed to the adverse effect of the CPB [54]. The CPB duration seems to be a major determinant for the development of postoperative thrombocytopenia [66]. However, this mechanism could change according to the different type of valve prosthesis implanted.

In 2006, Le Guyader and colleagues observed platelet activation after aortic valve replacements with two kinds of mechanical valves and three kinds of tissue valves [67]. They found platelet activation in all of the prostheses on the eighth postoperative day (POD) and was still present in the bioprosthesis group at the two month follow-up [67]. Ravenni and co-workers reported a decrease in platelet counts in different bioprosthesis types on the first POD; a stentless bioprosthesis showed a significant decrease in the postoperative platelet count compared with stented tissue valves [68]. Similarly, in 2016 Stanger and colleagues reported a significant decrease in the postoperative platelet count in three types of bioprostheses [69]. Nevertheless, those tissue valves were not associated with bleeding complications [69].

Several investigators have reported stentless bioprostheses as risk factors for postoperative thrombocytopenia [70-73]. Although showing a good hemodynamic performance, stentless bioprosthesis implantation has been associated with postoperative thrombocytopenia [63]. However, a decreased postoperative platelet count did not affect the postoperative outcomes compared with stented bioprostheses except for an increased rate of red blood cell transfusions [63]. The postoperative platelet count decreased from $60 \%$ to $77 \%$ after a 
stentless bioprosthesis implantation [63]. Likewise, the platelet count fell from 53\% to 60\% after the implantation of rapid deployment valves (RDVs) [63]. Like the stentless valves, thrombocytopenia after RDV implantation seemed to occur in the first PODs before a slow recovery within 7 to 10 days after surgery $[69,74-76]$. The origin of thrombocytopenia after RDV implantation is still unknown. To explain the phenomenon in RDVs, investigators have advanced analogous hypotheses to those for thrombocytopenia after the implantation of stentless bioprostheses [74-77].

Interestingly, thrombocytopenia and platelet disorders do not only occur after the implantation of surgical bioprostheses [63]. Several papers have reported that transcatheter aortic valve implantation (TAVI) patients have also experienced a temporary platelet count decrease following the procedure [63,78-90]. The platelet count drop ranged from $21 \%$ to $72 \%$ after TAVI with associated adverse outcomes $[63,89,91]$. The cause was most likely multifactorial; the valve design, the shear stress, the valve size, the length and type of the procedure and the amount of low-osmolar contrast agents used can interact together and elicit platelet destruction and increase the coagulation cascade and the inflammatory process leading to thrombocytopenia $[63,89,90]$. Moreover, mispositioning and TAVI migration are predictors of a platelet count decrease supporting the hypothesis of shear stress in the origin of thrombocytopenia [12]. Furthermore, thrombocytopenia occurs more frequently in patients with balloon-expandable valves (BEVs) $[63,85,87,90]$. Considering the prosthesis shape, the use of large sheaths, pre-dilatation and surgical cut-down for femoral access, a BEV was identified as a new predictor of TAVI related thrombocytopenia $[63,85,87,90]$. Furthermore, TAVI related thrombocytopenia has been found to be associated with increased early and overall mortality after TAVI [63,89].

Future investigations should focus on defining thrombocytopenia and platelet disorders after the implantation of biological prosthesis to improve patient management and to reduce adverse events.

\section{Heparin-Induced Thrombocytopenia}

Heparin-induced thrombocytopenia (HIT) is a rare drawback after the exposure to either unfractionated heparin (UFH) or low molecular weight heparin (LMWH). Heparin is a worldwide used anticoagulant because of its efficiency, accessibility, reversibility and costs beyond compare.

HIT is characterized by a decreased platelet count of about $30-50 \%$ leading to severe thrombocytopenia $\left(<100 \times 10^{9} / \mathrm{L}\right)$. However, typical factors such as hemodilution must be ruled out in the diagnostic phase. Hemorrhagic complications are rare whereas thromboembolic events occur more frequently (up to $~ 50 \%$ if not diagnosed/treated) and might jeopardize the patient's outcome [92]. HIT is estimated to occur once in 1500 hospitalizations in the United States with high-risk cardiac surgery patients [92]. Furthermore, HIT is associated with a four-fold higher in-hospital mortality, three-fold longer median hospitalization time and four-fold higher costs of hospitalization compared with thrombocytopenia from other etiologies [93].

HIT's risk factors are both host and drug related; the female gender has been linked to a doubled risk of developing HIT [94] while a younger age ( $<40$ years) seems to entail a milder risk [95]. Furthermore, recent genome-wide association studies (GWAS) have highlighted candidate gene variants (i.e., the HLA-DRB3*01:01 allele) associated with a risk of HIT [96-98]. Among the drug related factors, the duration of heparin exposure plays a major role with a shorter span carrying a lower risk [99]. UFH therapy is more likely to lead to HIT compared with LMWH [100-103]. Platelet factor 4 (PF4), indeed, forms oligomers binding multiple UFH oligosaccharides that further share several PF4 tetramers, leading to the assembly of ultra-large antigenic complexes (ULCs) $[60,104,105]$. Bovine heparin may carry a higher risk for HIT compared with porcine heparin [106,107].

HIT is a serious immune mediated adverse reaction to heparin polyanions caused by pathogenic immunoglobulin $\mathrm{G}(\mathrm{IgG})$ antibodies. IgGs bind to complexes of heparin and $\mathrm{PF} 4$, a cationic chemokine stored within platelet alpha granules characterized by a high 
affinity for anionic molecules. These complexes are optimally formed at a stoichiometric concentration (molar ratio 1:1). Noxae such as major surgery, a CPB and mechanical circulatory supports (MCSs) (e.g., ECMO and ventricular assist devices (VADs)) can trigger massive platelet activation and subsequent additional PF4 release [108]. ULCs consequently cross-link the surface receptors of platelets (FC $\gamma$ IIa) leading to a switch toward a hyperaggregative phenotype $[19,109,110]$. The process promotes a complex cascade of events involving endothelial cells, immune cells and NETs and coagulation factors and other circulating molecules $[19,109,110]$.

The mutual effect of pre-existent vascular stress, incessant platelet activation and the need of profound heparinization make adult cardiac surgery the most prone setting for HIT occurrence (50\% to 70\%) [111-114]. Conversely, pediatric patients show lower rates of seroconversions (0-2\%) most likely due to the absence of chronic vascular insults [91]. Despite the recurrence of anti-PF4/heparin antibodies in heart surgery patients, only 2-3\% develop HIT [115]. The detection of antibodies is required to diagnose HIT. In addition to the low platelet count, the " $4 \mathrm{Ts}$ " score is a bedside tool used to estimate the probability of HIT that improves the specificity of antibody tests in cardiac patients (Table 1) [116].

Table 1. Estimating the pre-test probability of HIT: the " 4 Ts".

\begin{tabular}{cccc}
\hline “4 Ts" Category & 2 Points & 1 Point & 0 Points \\
\hline Thrombocytopenia & $\begin{array}{c}\text { Platelet count fall }>50 \% \text { AND } \\
\text { platelet nadir } \geq 20 \times 10^{9} / \mathrm{L}\end{array}$ & $\begin{array}{c}\text { Platel count fall } 30-50 \% \text { OR platelet } \\
\text { nadir 10-19 } \times 10^{9} / \mathrm{L}\end{array}$ & $\begin{array}{c}\text { Platelet count fall }<30 \% \text { OR } \\
\text { platelet nadir }<10 \times 10^{9} / \mathrm{L}\end{array}$ \\
\hline $\begin{array}{c}\text { Timing of platelet } \\
\text { count fall }\end{array}$ & $\begin{array}{c}\text { Clear onset between days } \\
\text { 5- OR platelet fall } \leq 1 \text { day } \\
\text { (prior heparin exposure } \\
\text { within 30 days) }\end{array}$ & $\begin{array}{c}\text { Consistent with days } 5-10 \text { fall but not } \\
\text { clear; onset after day 10 OR fall } \\
\leq 1 \text { day (prior heparin exposure } \\
\text { 30-100 days ago) }\end{array}$ & $\begin{array}{c}\text { Platelet count fall }<4 \text { days } \\
\text { without recent exposure }\end{array}$ \\
$\begin{array}{c}\text { Thrombosis or other } \\
\text { sequelae }\end{array}$ & $\begin{array}{c}\text { New thrombosis OR skin } \\
\text { necrosis; acute systemic } \\
\text { reaction postintravenous } \\
\text { heparin bolus }\end{array}$ & $\begin{array}{c}\text { Progressive or recurrent thrombosis } \\
\text { or non-necrotizing (erythematous) } \\
\text { skin lesions or suspected thrombosis } \\
\text { (not proven) }\end{array}$ & None \\
\hline $\begin{array}{c}\text { Other causes for } \\
\text { thrombocytopenia }\end{array}$ & None apparent & Possible & Definite \\
\hline
\end{tabular}

Moreover, preoperative evidence of anti-PF4/heparin antibodies is reported in 5\% to 22\% of cardiac patients [117]. However, an uncertain prognostic value is attributed to this finding because of the controversial data about the preoperative positivity to anti-PF4/heparin antibodies and postoperative HIT, thrombosis and an adverse outcome [19,118-121]. Therefore, routine screening for such antibodies is discouraged (unless clinically evident HIT signs are manifested or in cases of a history of HIT).

HIT occurrence makes heart surgery a challenging event that can counteract the results of even the most successful operation. This eventuality should imply the deferral of any elective procedure until the results of laboratory tests are available. However, cardiac surgery is a practice in which deferring a procedure is not always a feasible option. Hence, several alternative strategies exist; pharmacological agents such as direct thrombin inhibitors (DTIs), factor Xa inhibitors (i.e., fondaparinux) and platelet inhibitors (i.e., prostaglandins) are plausible options.

Among DTIs, bivalirudin is the most used alternative agent in cardiac surgery showing a comparable efficiency and similar perioperative morbidity rates with heparin [122,123]. Furthermore, while DTIs are usually monitored by activated partial thromboplastin time (aPTT), the activated clotting time (ACT) appeared to be reliable in monitoring anticoagulation with bivalirudin during a CPB [121]. Other DTIs such as argatroban and danaparoid are not recommended as alternative therapies during a CPB [124,125]. Several studies have reported bleeding after therapy discontinuation and unexpected thrombosis $(\mathrm{ACT}>500 \mathrm{~s})[124,125]$. While HIT treatment with either fondaparinux or other molecules 
(i.e., epoprostenol, iloprost) is almost anecdotal [126], off-pump procedures and a plasma exchange represent other controversial approaches to minimizing heparin exposure [127-130].

\section{Conclusions}

Platelet functional or structural alterations are not epiphenomena of the acute reaction to CPB-assisted cardiac surgery, biological bioprosthesis and ECMO but rather have a major role in the thread linking hemostasis, inflammation and innate immunity. The multiple direct/indirect mechanisms that regulate this connection are still partially unclear. However, further studies addressing the pathobiological dynamics concurring to the abovementioned quantitative (i.e., thrombocytopenia) and qualitative (i.e., platelet activation and a shift towards a proinflammatory phenotype) platelet derangements in a cardiac surgery setting and ECLS may provide new insights possibly leading to improved patient outcomes.

Author Contributions: Conceptualization E.S., F.J.; methodology, G.F.S., D.P.; validation, H.t.C.; investigation, E.S., F.J.; resources, E.S., F.J.; data curation, R.L.; writing-original draft preparation, E.S., F.J.; final review and editing, G.F.S., H.t.C., D.P., R.L.; visualization, E.S., F.J. All authors have read and agreed to the published version of the manuscript.

Funding: This research received no external funding.

Institutional Review Board Statement: Not applicable.

Informed Consent Statement: Not applicable.

Data Availability Statement: Not applicable.

Conflicts of Interest: The authors declare no conflict of interest.

\section{References}

1. Van Der Meijden, P.E.J.; Heemskerk, J.W.M. Platelet biology and functions: New concepts and clinical perspectives. Nat. Rev. Cardiol. 2019, 16, 166-179. [CrossRef]

2. Gawaz, M.; Langer, H.; May, A.E. Platelets in inflammation and atherogenesis. J. Clin. Investig. 2005, 115, 3378-3384. [CrossRef]

3. Mezger, M.; Gobel, K.; Kraft, P.; Meuth, S.G.; Kleinschnitz, C.; Langer, H.F. Platelets and vascular inflammation of the brain. Hämostaseologie 2015, 35, 244-251. [CrossRef]

4. Engelmann, B.; Massberg, S. Thrombosis as an intravascular effector of innate immunity. Nat. Rev. Immunol. 2012, 13, 34-45. [CrossRef]

5. $\quad$ Carestia, A.; Mena, H.A.; Olexen, C.M.; Wilczyñski, J.M.O.; Negrotto, S.; Errasti, A.E.; Gómez, R.M.; Jenne, C.N.; Silva, E.A.C.; Schattner, M. Platelets Promote Macrophage Polarization toward Pro-inflammatory Phenotype and Increase Survival of Septic Mice. Cell Rep. 2019, 28, 896-908.e5. [CrossRef]

6. Garraud, O.; Ecognasse, F. Are Platelets Cells? And if Yes, are They Immune Cells? Front. Immunol. 2015, 6, 70. [CrossRef]

7. Griffin, B.R.; Bronsert, M.; Reece, T.B.; Pal, J.D.; Cleveland, J.C.; Fullerton, D.A.; Gist, K.M.; Jovanovich, A.; Jalal, D.; Faubel, S.; et al. Thrombocytopenia After Cardiopulmonary Bypass Is Associated With Increased Morbidity and Mortality. Ann. Thorac. Surg. 2020, 110, 50-57. [CrossRef]

8. Kertai, M.D.; Zhou, S.; Karhausen, J.A.; Cooter, M.; Jooste, E.; Li, Y.-J.; White, W.D.; Aronson, S.; Podgoreanu, M.V.; Gaca, J.G.; et al. Platelet Counts, Acute Kidney Injury, and Mortality after Coronary Artery Bypass Grafting Surgery. Anesthesiology 2016, 124, 339-352. [CrossRef]

9. Jiritano, F.; Lorusso, R.; Santarpino, G. Causes of Thrombocytopenia in Cardiac Surgery: Looking for the Holy Grail? Ann. Thorac. Surg. 2020, 110, 751-752. [CrossRef]

10. Squiccimarro, E.; Labriola, C.; Malvindi, P.G.; Margari, V.; Guida, P.; Visicchio, G.; Kounakis, G.; Favale, A.; Dambruoso, P.; Mastrototaro, G.; et al. Prevalence and Clinical Impact of Systemic Inflammatory Reaction After Cardiac Surgery. J. Cardiothorac. Vasc. Anesthesia 2019, 33, 1682-1690. [CrossRef]

11. Deptula, J.; Glogowski, K.; Merrigan, K.; Hanson, K.; Felix, D.; Hammel, J.; Duncan, K. Evaluation of biocompatible cardiopulmonary bypass circuit use during pediatric open heart surgery. J. Extra Corporeal Technol. 2006, 38, $22-26$.

12. Tabuchi, N.; Shibamiya, A.; Koyama, T.; Fukuda, T.; Van Oeveren, W.; Sunamori, M. Activated Leukocytes Adsorbed on the Surface of an Extracorporeal Circuit. Artif. Organs 2003, 27, 591-594. [CrossRef]

13. Vardon-Bounes, F.; Ruiz, S.; Gratacap, M.-P.; Garcia, C.; Payrastre, B.; Minville, V. Platelets Are Critical Key Players in Sepsis. Int. J. Mol. Sci. 2019, 20, 3494. [CrossRef]

14. Mezger, M.; Nording, H.; Sauter, R.; Graf, T.; Heim, C.; Von Bubnoff, N.; Ensminger, S.M.; Langer, H.F. Platelets and Immune Responses During Thromboinflammation. Front. Immunol. 2019, 10, 1731. [CrossRef] 
15. Rossaint, J.; Kühne, K.; Skupski, J.; Van Aken, H.; Looney, M.R.; Hidalgo, A.; Zarbock, A. Directed transport of neutrophil-derived extracellular vesicles enables platelet-mediated innate immune response. Nat. Commun. 2016, 7, 13464. [CrossRef]

16. Zahler, S.; Massoudy, P.; Hartl, H.; Hähnel, C.; Meisner, H.; Becker, B.F. Acute cardiac inflammatory responses to postischemic reperfusion during cardiopulmonary bypass. Cardiovasc. Res. 1999, 41, 722-730. [CrossRef]

17. Warltier, D.C.; Laffey, J.G.; Boylan, J.F.; Cheng, D.C.H. The Systemic Inflammatory Response to Cardiac Surgery. Anesthesiology 2002, 97, 215-252. [CrossRef]

18. Clark, S.R.; Ma, A.C.; A Tavener, S.; McDonald, B.; Goodarzi, Z.; Kelly, M.M.; Patel, K.D.; Chakrabarti, S.; McAvoy, E.; Sinclair, G.D.; et al. Platelet TLR4 activates neutrophil extracellular traps to ensnare bacteria in septic blood. Nat. Med. 2007, 13, 463-469. [CrossRef]

19. Perdomo, J.; Leung, H.H.L.; Ahmadi, Z.; Yan, F.; Chong, J.J.H.; Passam, F.H.; Chong, B.H. Neutrophil activation and NETosis are the major drivers of thrombosis in heparin-induced thrombocytopenia. Nat. Commun. 2019, 10, 1322. [CrossRef]

20. Rossaint, J.; Herter, J.M.; Van Aken, H.; Napirei, M.; Döring, Y.; Weber, C.; Soehnlein, O.; Zarbock, A. Synchronized integrin engagement and chemokine activation is crucial in neutrophil extracellular trap-mediated sterile inflammation. Blood 2014, 123, 2573-2584. [CrossRef]

21. Orlova, V.V.; Choi, E.Y.; Xie, C.; Chavakis, E.; Bierhaus, A.; Ihanus, E.; Ballantyne, C.M.; Gahmberg, C.G.; E Bianchi, M.; Nawroth, P.P.; et al. A novel pathway of HMGB1-mediated inflammatory cell recruitment that requires Mac-1-integrin. EMBO J. 2007, 26, 1129-1139. [CrossRef]

22. Maugeri, N.; Campana, L.; Gavina, M.; Covino, C.; De Metrio, M.; Panciroli, C.; Maiuri, L.; Maseri, A.; D’Angelo, A.; Bianchi, M.E.; et al. Activated platelets present high mobility group box 1 to neutrophils, inducing autophagy and promoting the extrusion of neutrophil extracellular traps. J. Thromb. Haemost. 2014, 12, 2074-2088. [CrossRef]

23. Cognasse, F.; Nguyen, K.A.; Damien, P.; McNicol, A.; Pozzetto, B.; Hamzeh-Cognasse, H.; Garraud, O. The inflammatory role of platelets via their TLRs and Siglec receptors. Front. Immunol. 2015, 6, 83. [CrossRef]

24. Weyrich, A.S.; Elstad, M.R.; McEver, R.P.; McIntyre, T.M.; Moore, K.L.; Morrissey, J.H.; Prescott, S.M.; A Zimmerman, G. Activated platelets signal chemokine synthesis by human monocytes. J. Clin. Investig. 1996, 97, 1525-1534. [CrossRef] [PubMed]

25. Blair, P.; Flaumenhaft, R. Platelet $\alpha$-granules: Basic biology and clinical correlates. Blood Rev. 2009, 23, 177-189. [CrossRef]

26. Rolfes, V.; Ribeiro, L.S.; Hawwari, I.; Böttcher, L.; Rosero, N.; Maasewerd, S.; Santos, M.L.S.; Próchnicki, T.; Silva, C.M.D.S.; Wanderley, C.W.D.S.; et al. Platelets Fuel the Inflammasome Activation of Innate Immune Cells. Cell Rep. 2020, $31,107615$. [CrossRef]

27. Peerschke, E.I.B.; Yin, W.; Ghebrehiwet, B. Complement activation on platelets: Implications for vascular inflammation and thrombosis. Mol. Immunol. 2010, 47, 2170-2175. [CrossRef]

28. Del Conde, I.; Crúz, M.A.; Zhang, H.; López, J.A.; Afshar-Kharghan, V. Platelet activation leads to activation and propagation of the complement system. J. Exp. Med. 2005, 201, 871-879. [CrossRef]

29. Hamad, O.A.; Ekdahl, K.N.; Nilsson, P.H.; Andersson, J.; Magotti, P.; Lambris, J.D.; Nilsson, B. Complement activation triggered by chondroitin sulfate released by thrombin receptor-activated platelets. J. Thromb. Haemost. 2008, 6, 1413-1421. [CrossRef]

30. Yin, W.; Ghebrehiwet, B.; Peerschke, E.I.B. Expression of complement components and inhibitors on platelet microparticles. Platelets 2008, 19, 225-233. [CrossRef]

31. Morrell, C.N.; Aggrey, A.A.; Chapman, L.M.; Modjeski, K.L. Emerging roles for platelets as immune and inflammatory cells. Blood 2014, 123, 2759-2767. [CrossRef]

32. Mause, S.F.; Von Hundelshausen, P.; Zernecke, A.; Koenen, R.R.; Weber, C. Platelet Microparticles. Arter. Thromb. Vasc. Biol. 2005, 25, 1512-1518. [CrossRef]

33. Rousseau, M.; Duchez, A.-C.; Lee, C.H.C.; Boilard, E.; Laffont, B.; Corduan, A.; Provost, P. Platelet microparticles reprogram macrophage gene expression and function. Thromb. Haemost. 2016, 115, 311-323. [CrossRef]

34. Gidlöf, O.; Van Der Brug, M.; Öhman, J.; Gilje, P.; Olde, B.; Wahlestedt, C.; Erlinge, D. Platelets activated during myocardial infarction release functional miRNA, which can be taken up by endothelial cells and regulate ICAM1 expression. Blood 2013, 121, 3908-3917. [CrossRef] [PubMed]

35. Laffont, B.; Corduan, A.; Plé, H.; Duchez, A.-C.; Cloutier, N.; Boilard, E.; Provost, P. Activated platelets can deliver mRNA regulatory Ago2•microRNA complexes to endothelial cells via microparticles. Blood 2013, 122, 253-261. [CrossRef] [PubMed]

36. Poon, K.-S.; Palanisamy, K.; Chang, S.-S.; Sun, K.-T.; Chen, K.-B.; Li, P.-C.; Lin, T.-C.; Li, C.-Y. Plasma exosomal miR-223 expression regulates inflammatory responses during cardiac surgery with cardiopulmonary bypass. Sci. Rep. 2017, 7, 1-11. [CrossRef]

37. Müller, I.; Klocke, A.; Alex, M.; Kotzsch, M.; Luther, T.; Morgenstern, E.; Zieseniss, S.; Zahler, S.; Preissner, K.; Engelmann, B. Intravascular tissue factor initiates coagulation via circulating microvesicles and platelets. FASEB J. 2003, 17, 1-20. [CrossRef] [PubMed]

38. Mukai, N.; Nakayama, Y.; Ishi, S.; Ogawa, S.; Maeda, S.; Anada, N.; Murakami, S.; Mizobe, T.; Sawa, T.; Nakajima, Y. Changes in MicroRNA Expression Level of Circulating Platelets Contribute to Platelet Defect After Cardiopulmonary Bypass. Crit. Care Med. 2018, 46, e761-e767. [CrossRef]

39. Murase, M.; Nakayama, Y.; Sessler, D.; Mukai, N.; Ogawa, S.; Nakajima, Y. Changes in platelet Bax levels contribute to impaired platelet response to thrombin after cardiopulmonary bypass: Prospective observational clinical and laboratory investigations. $\mathrm{Br}$. J. Anaesth. 2017, 119, 1118-1126. [CrossRef] 
40. De Backer, D.; Dubois, M.-J.; Schmartz, D.; Koch, M.; Ducart, A.; Barvais, L.; Vincent, J.-L. Microcirculatory Alterations in Cardiac Surgery: Effects of Cardiopulmonary Bypass and Anesthesia. Ann. Thorac. Surg. 2009, 88, 1396-1403. [CrossRef] [PubMed]

41. Koning, N.J.; Atasever, B.; Vonk, A.B.; Boer, C. Changes in Microcirculatory Perfusion and Oxygenation During Cardiac Surgery With or Without Cardiopulmonary Bypass. J. Cardiothorac. Vasc. Anesthesia 2014, 28, 1331-1340. [CrossRef]

42. Di Dedda, U.; Ranucci, M.; Porta, A.; Bari, V.; Ascari, A.; Fantinato, A.; Baryshnikova, E.; Cotza, M. The combined effects of the microcirculatory status and cardiopulmonary bypass on platelet count and function during cardiac surgery. Clin. Hemorheol. Microcirc. 2018, 70, 327-337. [CrossRef] [PubMed]

43. Karhausen, J.; Choi, H.W.; Maddipati, K.R.; Mathew, J.P.; Ma, Q.; Boulaftali, Y.; Lee, R.H.; Bergmeier, W.; Abraham, S.N. Platelets trigger perivascular mast cell degranulation to cause inflammatory responses and tissue injury. Sci. Adv. 2020, 6, eaay6314 [CrossRef]

44. Hill, J.D.; O’Brien, T.G.; Murray, J.J.; Dontigny, L.; Bramson, M.L.; Osborn, J.J.; Gerbode, F. Prolonged Extracorporeal Oxygenation for Acute Post-Traumatic Respiratory Failure (Shock-Lung Syndrome). N. Engl. J. Med. 1972, 286, 629-634. [CrossRef]

45. Chen, Y.-S.; Lin, J.-W.; Yu, H.-Y.; Ko, W.-J.; Jerng, J.-S.; Chang, W.-T.; Chen, W.-J.; Huang, S.-C.; Chi, N.-H.; Wang, C.-H.; et al. Cardiopulmonary resuscitation with assisted extracorporeal life-support versus conventional cardiopulmonary resuscitation in adults with in-hospital cardiac arrest: An observational study and propensity analysis. Lancet 2008, 372, 554-561. [CrossRef]

46. Sy, E.; Sklar, M.C.; Lequier, L.; Fan, E.; Kanji, H.D. Anticoagulation practices and the prevalence of major bleeding, thromboembolic events, and mortality in venoarterial extracorporeal membrane oxygenation: A systematic review and meta-analysis. J. Crit. Care 2017, 39, 87-96. [CrossRef]

47. Yoshimoto, Y.; Hasebe, T.; Takahashi, K.; Amari, M.; Nagashima, S.; Kamijo, A.; Hotta, A.; Takahashi, K.; Suzuki, T. Ultrastructural characterization of surface-induced platelet activation on artificial materials by transmission electron microscopy. Microsc. Res. Tech. 2013, 76, 342-349. [CrossRef]

48. Chen, Z.; Mondal, N.K.; Zheng, S.; Koenig, S.C.; Slaughter, M.S.; Griffith, B.P.; Wu, Z.J. High shear induces platelet dysfunction leading to enhanced thrombotic propensity and diminished hemostatic capacity. Platelets 2017, 30, 112-119. [CrossRef]

49. Sun, W.; Wang, S.; Chen, Z.; Zhang, J.; Li, T.; Arias, K.; Griffith, B.P.; Wu, Z.J. Impact of high mechanical shear stress and oxygenator membrane surface on blood damage relevant to thrombosis and bleeding in a pediatric ECMO circuit. Artif. Organs 2020, 44, 717-726. [CrossRef]

50. Lukito, P.; Wong, A.; Jing, J.; Arthur, J.F.; Marasco, S.F.; Murphy, D.A.; Bergin, P.J.; Shaw, J.A.; Collecutt, M.; Andrews, R.K.; et al. Mechanical circulatory support is associated with loss of platelet receptors glycoprotein Ib $\alpha$ and glycoprotein VI. J. Thromb. Haemost. 2016, 14, 2253-2260. [CrossRef]

51. Chung, J.H.; Yeo, H.J.; Kim, D.; Lee, S.M.; Han, J.; Kim, M.; Cho, W.H. Changes in the Levels of Beta-thromboglobulin and Inflammatory Mediators during Extracorporeal Membrane Oxygenation Support. Int. J. Artif. Organs 2017, 40, 575-580. [CrossRef]

52. Kalbhenn, J.; Schlagenhauf, A.; Rosenfelder, S.; Schmutz, A.; Zieger, B. Acquired von Willebrand syndrome and impaired platelet function during venovenous extracorporeal membrane oxygenation: Rapid onset and fast recovery. J. Hear. Lung Transplant. 2018, 37, 985-991. [CrossRef]

53. Fuchs, G.; Berg, N.; Broman, L.M.; Wittberg, L.P. Flow-induced platelet activation in components of the extracorporeal membrane oxygenation circuit. Sci. Rep. 2018, 8, 1-9. [CrossRef]

54. Arachchillage, D.J.; Laffan, M.; Khanna, S.; Vandenbriele, C.; Kamani, F.; Passariello, M.; Rosenberg, A.; Aw, T.C.; Banya, W.; Ledot, S.; et al. Frequency of Thrombocytopenia and Heparin-Induced Thrombocytopenia in Patients Receiving Extracorporeal Membrane Oxygenation Compared With Cardiopulmonary Bypass and the Limited Sensitivity of Pretest Probability Score. Crit. Care Med. 2020, 48, e371-e379. [CrossRef]

55. The Extracorporeal Life Support Organization (ELSO). Extracorporeal Life Support Organization (ELSO) General Guidelines for All ECLS Cases. Available online: https://www.elso.org/Portals/0/Files/elsoanticoagulationguideline8-2014-table-contents.pdf (accessed on 26 July 2020).

56. Jiritano, F.; Serraino, G.F.; Cate, H.T.; Fina, D.; Matteucci, M.; Mastroroberto, P.; Lorusso, R. Platelets and extra-corporeal membrane oxygenation in adult patients: A systematic review and meta-analysis. Intensiv. Care Med. 2020, 46, 1154-1169. [CrossRef]

57. Abrams, D.; Baldwin, M.R.; Champion, M.; Agerstrand, C.; Eisenberger, A.; Bacchetta, M.; Brodie, D. Thrombocytopenia and extracorporeal membrane oxygenation in adults with acute respiratory failure: A cohort study. Intensiv. Care Med. 2016, 42, 844-852. [CrossRef]

58. Panigada, M.; Artoni, A.; Passamonti, S.M.; Maino, A.; Mietto, C.; L'Acqua, C.; Cressoni, M.; Boscolo, M.; Tripodi, A.; Bucciarelli, P.; et al. Hemostasis changes during veno-venous extracorporeal membrane oxy-genation for respiratory support in adults. Minerva Anestesiol. 2016, 82, 170-179.

59. Ang, A.L.; Teo, D.; Lim, C.H.; Leou, K.K.; Tien, S.L.; Koh, M.B.C. Blood transfusion requirements and independent predictors of increased transfusion requirements among adult patients on extracorporeal membrane oxygenation - a single centre experience. Vox Sang. 2009, 96, 34-43. [CrossRef]

60. Rauova, L.; Poncz, M.; McKenzie, S.E.; Reilly, M.P.; Arepally, G.; Weisel, J.W.; Nagaswami, C.; Cines, D.B.; Sachais, B.S.; Herre, J.; et al. Ultralarge complexes of PF4 and heparin are central to the pathogenesis of heparin-induced thrombocytopenia. Blood 2005, 105, 131-138. [CrossRef] 
61. Ontaneda, A.; Annich, G.M. Novel Surfaces in Extracorporeal Membrane Oxygenation Circuits. Front. Med. 2018, 5, 321. [CrossRef]

62. Klein, S.; Hesselmann, F.; Djeljadini, S.; Berger, T.; Thiebes, A.L.; Schmitz-Rode, T.; Jockenhoevel, S.; Cornelissen, C.G. EndOxy: Dynamic Long-Term Evaluation of Endothelialized Gas Exchange Membranes for a Biohybrid Lung. Ann. Biomed. Eng. 2020, 48, 747-756. [CrossRef]

63. Jiritano, F.; Santarpino, G.; Serraino, G.F.; Cate, H.T.; Matteucci, M.; Fina, D.; Mastroroberto, P.; Lorusso, R. Peri-procedural thrombocytopenia after aortic bioprosthesis implant: A systematic review and meta-analysis comparison among conventional, stentless, rapid-deployment, and transcatheter valves. Int. J. Cardiol. 2019, 296, 43-50. [CrossRef]

64. Steinlechner, B.; Dworschak, M.; Birkenberg, B.; Duris, M.; Zeidler, P.; Fischer, H.; Milosevic, L.; Wieselthaler, G.; Wolner, E.; Quehenberger, P.; et al. Platelet Dysfunction in Outpatients With Left Ventricular Assist Devices. Ann. Thorac. Surg. 2009, 87, 131-137. [CrossRef]

65. Chen, Z.; Mondal, N.K.; Ding, J.; Koenig, S.C.; Slaughter, M.S.; Wu, Z.J. Paradoxical Effect of Nonphysiological Shear Stress on Platelets and von Willebrand Factor. Artif. Organs 2016, 40, 659-668. [CrossRef]

66. Vogt, F.; Moscarelli, M.; Pollari, F.; Kalisnik, J.M.; Pfeiffer, S.; Fittkau, M.; Sirch, J.; Pförringer, D.; Jessl, J.; Eckner, D.; et al. Two approaches-one phenomenon—thrombocytopenia after surgical and transcatheter aortic valve replacement. J. Card. Surg. 2020, 35, 1186-1194. [CrossRef] [PubMed]

67. Le Guyader, A.; Watanabe, R.; Berbé, J.; Boumediene, A.; Cogné, M.; Laskar, M. Platelet activation after aortic prosthetic valve surgery. Interact. Cardiovasc. Thorac. Surg. 2005, 5, 60-64. [CrossRef]

68. Ravenni, G.; Celiento, M.; Ferrari, G.; Milano, A.; Scioti, G.; Pratali, S.; Bortolotti, U. Reduction in platelet count after aortic valve replacement: Comparison of three bioprostheses. J. Hear. Valve Dis. 2012, 21, 655-661.

69. Stanger, O.; Grabherr, M.; Gahl, B.; Longnus, S.; Meinitzer, A.; Fiedler, M.; Tevaearai, H.; Carrel, T. Thrombocytopaenia after aortic valve replacement with stented, stentless and sutureless bioprostheses. Eur. J. Cardio-Thoracic Surg. 2016, 51, 340-346. [CrossRef] [PubMed]

70. Yerebakan, C.; Kaminski, A.; Westphal, B.; Kundt, G.; Ugurlucan, M.; Steinhoff, G.; Liebold, A. Thrombocytopenia after aortic valve replacement with the Freedom Solo stentless bioprosthesis. Interact. Cardiovasc. Thorac. Surg. 2008, 7, 616-620. [CrossRef]

71. Hilker, L.; Wodny, M.; Ginesta, M.; Wollert, H.-G.; Eckel, L. Differences in the recovery of platelet counts after biological aortic valve replacement. Interact. Cardiovasc. Thorac. Surg. 2008, 8, 70-73. [CrossRef]

72. Miceli, A.; Gilmanov, D.; Murzi, M.; Parri, M.S.; Cerillo, A.; Bevilacqua, S.; Farneti, P.A.; Glauber, M. Evaluation of platelet count after isolated biological aortic valve replacement with Freedom Solo bioprosthesis. Eur. J. Cardio-Thoracic Surg. 2011, 41, 69-73. [CrossRef]

73. Piccardo, A.; Rusinaru, D.; Petitprez, B.; Marticho, P.; Vaida, I.; Tribouilloy, C.; Caus, T. Thrombocytopenia After Aortic Valve Replacement With Freedom Solo Bioprosthesis: A Propensity Study. Ann. Thorac. Surg. 2010, 89, 1425-1430. [CrossRef]

74. Sánchez, E.; Corrales, J.-A.; Fantidis, P.; Tarhini, I.S.; Khan, I.; Pineda, T.; González, J.-R. Thrombocytopenia after Aortic Valve Replacement with Perceval S Sutureless Bioprosthesis. J. Hear. Valve Dis. 2016, 25, 75-81.

75. Mujtaba, S.S.; Ledingham, S.; Shah, A.R.; Schueler, S.; Clark, S.; Pillay, T. Thrombocytopenia After Aortic Valve Replacement: Comparison Between Sutureless Perceval S Valve and Perimount Magna Ease Bioprosthesis. Braz. J. Cardiovasc. Surg. 2018, 33, 169-175. [CrossRef]

76. Andreas, M.; Wallner, S.; Habertheuer, A.; Rath, C.; Schauperl, M.; Binder, T.; Beitzke, D.; Rosenhek, R.; Loewe, C.; Wiedemann, D.; et al. Conventional versus rapid-deployment aortic valve replacement: A single-centre comparison between the Edwards Magna valve and its rapid-deployment successor. Interact. Cardiovasc. Thorac. Surg. 2016, 22, 799-805. [CrossRef]

77. Jiritano, F.; Cristodoro, L.; Malta, E.; Mastroroberto, P. Thrombocytopenia after sutureless aortic valve implantation: Comparison between Intuity and Perceval bioprostheses. J. Thorac. Cardiovasc. Surg. 2016, 152, 1631-1633. [CrossRef] [PubMed]

78. Gallet, R.; Seemann, A.; Yamamoto, M.; Hayat, D.; Mouillet, G.; Monin, J.-L.; Gueret, P.; Couetil, J.-P.; Dubois-Randé, J.-L.; Teiger, E.; et al. Effect of Transcatheter (via Femoral Artery) Aortic Valve Implantation on the Platelet Count and Its Consequences. Am. J. Cardiol. 2013, 111, 1619-1624. [CrossRef]

79. Dvir, D.; Généreux, P.; Barbash, I.M.; Kodali, S.; Ben-Dor, I.; Williams, M.; Torguson, R.; Kirtane, A.J.; Minha, S.; Badr, S.; et al. Acquired thrombocytopenia after transcatheter aortic valve replacement: Clinical correlates and association with outcomes. Eur. Hear. J. 2014, 35, 2663-2671. [CrossRef] [PubMed]

80. McCabe, J.M.; Huang, P.-H.; Riedl, L.A.; Ba, S.R.D.; Rn, J.G.; Rn, A.C.C.; Davidson, M.J.; Eisenhauer, A.C.; Welt, F.G. Incidence and implications of idiopathic thrombocytopenia following transcatheter aortic valve replacement with the Edwards Sapien@valves: A single center experience. Catheter. Cardiovasc. Interv. 2013, 83, 633-641. [CrossRef]

81. Gul, M.; Uyarel, H.; Akgul, O.; Uslu, N.; Yildirim, A.; Eksik, A.; Aksu, H.U.; Ozal, E.; Pusuroglu, H.; Erol, M.K.; et al. Hematologic and Clinical Parameters After Transcatheter Aortic Valve Implantation (TAVI) in Patients With Severe Aortic Stenosis. Clin. Appl. Thromb. 2012, 20, 304-310. [CrossRef]

82. Flaherty, M.P.; Mohsen, A.; Moore, J.B.; Bartoli, C.R.; Schneibel, E.; Rawasia, W.; Williams, M.L.; Grubb, K.J.; Hirsch, G.A. Predictors and clinical impact of pre-existing and acquired thrombocytopenia following transcatheter aortic valve replacement. Catheter. Cardiovasc. Interv. 2014, 85, 118-129. [CrossRef] 
83. Sedaghat, A.; Falkenberg, N.; Sinning, J.-M.; Kulka, H.; Hammerstingl, C.; Nickenig, G.; Oldenburg, J.; Pötzsch, B.; Werner, N. TAVI induces an elevation of hemostasis-related biomarkers, which is not causative for post-TAVI thrombocytopenia. Int. J. Cardiol. 2016, 221, 719-725. [CrossRef] [PubMed]

84. Hernández-Enríquez, M.; Chollet, T.; Bataille, V.; Campelo-Parada, F.; Boudou, N.; Bouisset, F.; Grunenwald, E.; Porterie, J.; Freixa, X.; Regueiro, A.; et al. Comparison of the Frequency of Thrombocytopenia After Transfemoral Transcatheter Aortic Valve Implantation Between Balloon-Expandable and Self-Expanding Valves. Am. J. Cardiol. 2019, 123, 1120-1126. [CrossRef]

85. Jilaihawi, H.; Doctor, N.; Chakravarty, T.; Kashif, M.; Mirocha, J.; Cheng, W.; Lill, M.; Nakamura, M.; Gheorghiu, M.; Makkar, R. Major thrombocytopenia after balloon-expandable transcatheter aortic valve replacement: Prognostic implications and comparison to surgical aortic valve replacement. Catheter. Cardiovasc. Interv. 2015, 85, 130-137. [CrossRef]

86. Abu Saleh, W.K.; Tang, G.H.L.; Ahmad, H.; Cohen, M.; Undemir, C.; Lansman, S.L.S.L.; Reyes, M.; Barker, C.M.; Kleiman, N.S.; Reardon, M.J.; et al. Vascular complication can be minimized with a balloon-expandable, re-collapsible sheath in TAVR with a self-expanding bioprosthesis. Catheter. Cardiovasc. Interv. 2015, 88, 135-143. [CrossRef] [PubMed]

87. Mitrosz, M.; Kazimierczyk, R.; Sobkowicz, B.; Waszkiewicz, E.; Kralisz, P.; Frank, M.; Piszcz, J.; Galar, M.; Dobrzycki, S.; Musial, W.J.; et al. The causes of thrombocytopenia after transcatheter aortic valve implantation. Thromb. Res. 2017, 156, 39-44. [CrossRef] [PubMed]

88. Mitrosz, M.; Kazimierczyk, R.; Chlabicz, M.; Sobkowicz, B.; Waszkiewicz, E.; Lisowska, A.; Dobrzycki, S.; Musial, W.J.; Hirnle, T.; Kaminski, K.A.; et al. Perioperative thrombocytopenia predicts poor outcome in patients undergoing transcatheter aortic valve implantation. Adv. Med Sci. 2018, 63, 179-184. [CrossRef]

89. Takagi, H.; Hari, Y.; Nakashima, K.; Ueyama, H.; Kuno, T.; Ando, T. Impact of postprocedural thrombocytopenia on mortality after transcatheter aortic valve implantation. J. Cardiovasc. Med. 2020, 21, 318-324. [CrossRef]

90. Takahashi, S.; Yokoyama, N.; Watanabe, Y.; Katayama, T.; Hioki, H.; Yamamoto, H.; Kawasugi, K.; Kozuma, K. Predictor and Mid-Term Outcome of Clinically Significant Thrombocytopenia After Transcatheter Aortic Valve Selection. Circ. J. 2020, 84, 1020-1027. [CrossRef]

91. Mullen, M.P.; Wessel, D.L.; Thomas, K.C.; Gauvreau, K.; Neufeld, E.J.; McGowan, F.X.; Dinardo, J.A. The Incidence and Implications of Anti-Heparin-Platelet Factor 4 Antibody Formation in a Pediatric Cardiac Surgical Population. Anesthesia Analg. 2008, 107, 371-378. [CrossRef]

92. Dhakal, B.; Kreuziger, L.B.; Rein, L.; Kleman, A.; Fraser, R.; Aster, R.H.; Hari, P.; Padmanabhan, A. Disease burden, complication rates, and health-care costs of heparin-induced thrombocytopenia in the USA: A population-based study. Lancet Haematol. 2018, 5, e220-e231. [CrossRef]

93. Dhakal, P.; Giri, S.; Pathak, R.; Bhatt, V.R. Heparin Reexposure in Patients With a History of Heparin-Induced Thrombocytopenia. Clin. Appl. Thromb. 2013, 21, 626-631. [CrossRef] [PubMed]

94. Warkentin, T.E.; Sheppard, J.-A.I.; Sigouin, C.S.; Kohlmann, T.; Eichler, P.; Greinacher, A. Gender imbalance and risk factor interactions in heparin-induced thrombocytopenia. Blood 2006, 108, 2937-2941. [CrossRef]

95. Stein, P.D.; Hull, R.D.; Matta, F.; Yaekoub, A.Y.; Liang, J. Incidence of Thrombocytopenia in Hospitalized Patients with Venous Thromboembolism. Am. J. Med. 2009, 122, 919-930. [CrossRef] [PubMed]

96. Karnes, J.H.; Cronin, R.M.; Rollin, J.; Teumer, A.; Pouplard, C.; Shaffer, C.M.; Blanquicett, C.; Bowton, E.A.; Cowan, J.D.; Mosley, J.D.; et al. A genome-wide association study of heparin-induced thrombocyto - penia using an electronic medical record. Thromb. Haemost. 2015, 113, 772-781. [CrossRef]

97. Karnes, J.H.; Shaffer, C.M.; Cronin, R.; Bastarache, L.; Gaudieri, S.; James, I.; Pavlos, R.; Steiner, H.E.; Mosley, J.D.; Mallal, S.; et al. Influence of Human Leukocyte Antigen (HLA) Alleles and Killer Cell Immunoglobulin-Like Receptors (KIR) Types on Heparin-Induced Thrombocytopenia (HIT). Pharmacother. J. Hum. Pharmacol. Drug Ther. 2017, 37, 1164-1171. [CrossRef]

98. Witten, A.; Bolbrinker, J.; Barysenka, A.; Huber, M.; Rühle, F.; Nowak-Göttl, U.; Garbe, E.; Kreutz, R.; Stoll, M. Targeted resequencing of a locus for heparin-induced thrombocytopenia on chromosome 5 identified in a genome-wide association study. J. Mol. Med. 2018, 96, 765-775. [CrossRef]

99. Smythe, M.A.; Koerber, J.M.; Mattson, J.C. The Incidence of Recognized Heparin-Induced Thrombocytopenia in a Large, Tertiary Care Teaching Hospital. Chest 2007, 131, 1644-1649. [CrossRef] [PubMed]

100. Amiral, J.; Peynaud-Debayle, E.; Wolf, M.; Bridey, F.; Vissac, A.M.; Meyer, D. Generation of antibodies to heparin-PF4 com-plexes without thrombocytopenia in patients treated with unfractionated or low-molecular-weight heparin. Am. J. Hematol. 1996, 52, 90-95. [CrossRef]

101. Warkentin, T.E.; Sheppard, J.A.; Horsewood, P.; Simpson, P.J.; Moore, J.C.; Kelton, J.G. Impact of the patient population on the risk for heparin-induced thrombocytopenia. Blood 2000, 96, 1703-1708. [CrossRef] [PubMed]

102. Cuker, A.; Cines, U.B. How I treat heparin-induced thrombocytopenia. Blood 2012, 119, 2209-2218. [CrossRef]

103. McGowan, K.E.; Makari, J.; Diamantouros, A.; Bucci, C.; Rempel, P.; Selby, R.; Geerts, W. Reducing the hospital burden of heparin-induced thrombocytopenia: Impact of an avoid-heparin program. Blood 2016, 127, 1954-1959. [CrossRef]

104. Suvarna, S.; Espinasse, B.; Qi, R.; Lubica, R.; Poncz, M.; Cines, U.B.; Wiesner, M.R.; Arepally, G.M. Determinants of PF4/heparin immunogenicity. Blood 2007, 110, 4253-4260. [CrossRef]

105. Arepally, G.M.; Cines, D.B. Pathogenesis of heparin-induced thrombocytopenia. Transl. Res. 2020, 225, 131-140. [CrossRef]

106. Francis, J.L.; Palmer, G.J.; Moroose, R.; Drexler, A. Comparison of bovine and porcine heparin in heparin antibody formation after cardiac surgery. Ann. Thorac. Surg. 2003, 75, 17-22. [CrossRef] 
107. Ahmad, S. Heparin-induced thrombocytopenia: Impact of bovine versus porcine heparin in HIT pathogenesis. Front. Biosci. 2007, 12, 3312-3320. [CrossRef] [PubMed]

108. Greinacher, A.; Warkentin, T.E.; Chong, B.H. Heparin-induced thrombocytopenia. In Platelets, 4th ed.; Michelson, A.D., Ed.; Academic Press: New York, NY, USA, 2019; pp. 741-767.

109. Hayes, V.; Johnston, I.; Arepally, G.M.; McKenzie, S.E.; Cines, D.B.; Rauova, L.; Poncz, M. Endothelial antigen assembly leads to thrombotic complications in heparin-induced thrombocytopenia. J. Clin. Investig. 2017, 127, 1090-1098. [CrossRef] [PubMed]

110. Gollomp, K.; Kim, M.; Johnston, I.; Hayes, V.; Welsh, J.; Arepally, G.M.; Kahn, M.; Lambert, M.P.; Cuker, A.; Cines, D.B.; et al. Neutrophil accumulation and NET release contribute to thrombosis in HIT. JCI Insight 2018, 3, 99445. [CrossRef] [PubMed]

111. Bauer, T.L.; Arepally, G.; Konkle, B.A.; Mestichelli, B.; Shapiro, S.S.; Cines, D.B.; Poncz, M.; McNulty, S.; Amiral, J.; Hauck, W.W.; et al. Prevalence of Heparin-Associated Antibodies Without Thrombosis in Patients Undergoing Cardiopulmonary Bypass Surgery. Circ. 1997, 95, 1242-1246. [CrossRef]

112. Pouplard, C.; May, M.-A.; Iochmann, S.; Amiral, J.; Vissac, A.-M.; Marchand, M.; Gruel, Y. Antibodies to Platelet Factor 4-Heparin After Cardiopulmonary Bypass in Patients Anticoagulated With Unfractionated Heparin or a Low-Molecular-Weight Heparin. Circ. 1999, 99, 2530-2536. [CrossRef]

113. Koster, A.; Sänger, S.; Hansen, R.; Sodian, R.; Mertzlufft, F.; Harke, C.; Kuppe, H.; Hetzer, R.; Loebe, M. Prevalence and Persistence of Heparin/Platelet Factor 4 Antibodies in Patients with Heparin Coated and Noncoated Ventricular Assist Devices. ASAIO J. 2000, 46, 319-322. [CrossRef]

114. Schenk, S.; El-Banayosy, A.; Prohaska, W.; Arusoglu, L.; Morshuis, M.; Koester-Eiserfunke, W.; Kizner, L.; Murray, E.; Eichler, P.; Koerfer, R.; et al. Heparin-induced thrombocytopenia in patients receiving mechanical circulatory support. J. Thorac. Cardiovasc. Surg. 2006, 131, 1373-1381.e4. [CrossRef]

115. Warkentin, T.E.; Sheppard, J.I.; Sun, J.C.J.; Jung, H.; Eikelboom, J.W. Anti-PF4/heparin antibodies and venous graft occlusion in postcoronary artery bypass surgery patients randomized to postoperative unfractionated heparin or fondaparinux thromboprophylaxis. J. Thromb. Haemost. 2013, 11, 253-260. [CrossRef]

116. Demma, L.J.; Winkler, A.M.; Levy, J.H. A Diagnosis of Heparin-Induced Thrombocytopenia with Combined Clinical and Laboratory Methods in Cardiothoracic Surgical Intensive Care Unit Patients. Anesthesia Analg. 2011, 113, 697-702. [CrossRef]

117. Warkentin, T.E.; Arsenault, K.A.; Whitlock, R.; Eikelboom, J.; Yusuf, A.M. Prognostic importance of preoperative anti-PF4/heparin antibodies in patients undergoing cardiac surgery. Thromb. Haemost. 2012, 107, 8-14. [CrossRef] [PubMed]

118. Bennett-Guerrero, E.; Slaughter, T.F.; White, W.D.; Welsby, I.J.; Greenberg, C.S.; El-Moalem, H.; Ortel, T.L. Preoperative antiPF4/heparin antibody level predicts adverse outcome after cardiac surgery. J. Thorac. Cardiovasc. Surg. 2005, 130, 1567-1572. [CrossRef] [PubMed]

119. Everett, B.M.; Yeh, R.; Foo, S.Y.; Criss, D.; Van Cott, E.M.; Laposata, M.; Avery, E.G.; Hoffman, W.D.; Walker, J.; Torchiana, D.; et al. Prevalence of Heparin/Platelet Factor 4 Antibodies Before and After Cardiac Surgery. Ann. Thorac. Surg. 2007, 83, 592-597. [CrossRef] [PubMed]

120. Selleng, S.; Malowsky, B.; Itterman, T.; Bagemühl, J.; Wessel, A.; Wollert, H.-G.; Warkentin, T.E.; Greinacher, A. Incidence and clinical relevance of anti-platelet factor 4/heparin antibodies before cardiac surgery. Am. Hear. J. 2010, 160, 362-369. [CrossRef] [PubMed]

121. Mattioli, A.V.; Bonetti, L.; Zennaro, M.; Ambrosio, G.; Mattioli, G. Heparin/PF4 antibodies formation after heparin treatment: Temporal aspects and long-term follow-up. Am. Hear. J. 2009, 157, 589-595. [CrossRef]

122. Dyke, C.M.; Smedira, N.G.; Koster, A.; Aronson, S.; McCarthy, H.L.; Kirshner, R.; Lincoff, A.M.; Spiess, B.D. A comparison of bivalirudin to heparin with protamine reversal in patients undergoing cardiac surgery with cardiopulmonary bypass: The EVOLUTION-ON study. J. Thorac. Cardiovasc. Surg. 2006, 131, 533-539. [CrossRef] [PubMed]

123. Koster, A.; Dyke, C.M.; Aldea, G.; Smedira, N.G.; Ii, H.L.M.; Aronson, S.; Hetzer, R.; Avery, E.; Spiess, B.; Lincoff, A.M. Bivalirudin During Cardiopulmonary Bypass in Patients With Previous or Acute Heparin-Induced Thrombocytopenia and Heparin Antibodies: Results of the CHOOSE-ON Trial. Ann. Thorac. Surg. 2007, 83, 572-577. [CrossRef] [PubMed]

124. Follis, F.; Filippone, G.; Montalbano, G.; Floriano, M.; Lobianco, E.; D’Ancona, G.; Follis, M. Argatroban as a substitute of heparin during cardiopulmonary bypass: A safe alternative? Interact. Cardiovasc. Thorac. Surg. 2010, 10, 592-596. [CrossRef] [PubMed]

125. Agarwal, S.; Ullom, B.; Al-Baghdadi, Y.; Okumura, M. Challenges encountered with argatroban anticoagulation during cardiopulmonary bypass. Journal of Anaesthesiology, Clinical Pharmacology 2012, 28, 106-110. [CrossRef] [PubMed]

126. Antoniou, T.; Kapetanakis, E.I.; Theodoraki, K.; Rellia, P.; Thanopoulos, A.; Kotiou, M.; Zarkalis, D.; Alivizatos, P. Cardiac surgery in patients with heparin-induced thrombocytopenia using preoperatively determined dosages of iloprost. Hear. Surg. Forum 2002, $5,354-357$.

127. Voeller, R.K.; Melby, S.J.; Grizzell, B.E.; Moazami, N. Novel use of plasmapheresis in a patient with heparin-induced thrombocytopenia requiring urgent insertion of a left ventricular assist device under cardiopulmonary bypass. J. Thorac. Cardiovasc. Surg. 2010, 140, e56-e58. [CrossRef]

128. Jaben, E.A.; Torloni, A.S.; Pruthi, R.K.; Winters, J.L. Use of plasma exchange in patients with heparin-induced thrombocytopenia: A report of two cases and a review of the literature. J. Clin. Apher. 2011, 26, 219-224. [CrossRef] 
129. A Cannon, M.; Butterworth, J.; Riley, R.D.; Hyland, J.M. Failure of argatroban anticoagulation during off-pump coronary artery bypass surgery. Ann. Thorac. Surg. 2004, 77, 711-713. [CrossRef] [PubMed]

130. Dyke, C.M.; Aldea, G.; Koster, A.; Smedira, N.; Avery, E.; Aronson, S.; Spiess, B.D.; Lincoff, A.M. Off-Pump Coronary Artery Bypass with Bivalirudin for Patients with Heparin-Induced Thrombocytopenia or Antiplatelet Factor Four/Heparin Antibodies. Ann. Thorac. Surg. 2007, 84, 836-839. [CrossRef] [PubMed] 